\title{
Ocean Emission Effects on Aerosol-Cloud Interactions: Insights from Two Case Studies
}

\author{
Armin Sorooshian ${ }^{1,2}$ and Hanh T. Duong1 \\ ${ }^{1}$ Department of Chemical and Environmental Engineering, University of Arizona, P.O. Box 210011, Tucson, AZ 85721, USA \\ ${ }^{2}$ Department of Atmospheric Sciences, University of Arizona, P.O. Box 210081, Tucson, AZ 85721, USA
}

Correspondence should be addressed to Armin Sorooshian, armin@email.arizona.edu

Received 9 January 2010; Revised 28 February 2010; Accepted 24 April 2010

Academic Editor: Markus D. Petters

Copyright ( 2010 A. Sorooshian and H. T. Duong. This is an open access article distributed under the Creative Commons Attribution License, which permits unrestricted use, distribution, and reproduction in any medium, provided the original work is properly cited.

\begin{abstract}
Two case studies are discussed that evaluate the effect of ocean emissions on aerosol-cloud interactions. A review of the first case study from the eastern Pacific Ocean shows that simultaneous aircraft and space-borne observations are valuable in detecting links between ocean biota emissions and marine aerosols, but that the effect of the former on cloud microphysics is less clear owing to interference from background anthropogenic pollution and the difficulty with field experiments in obtaining a wide range of aerosol conditions to robustly quantify ocean effects on aerosol-cloud interactions. To address these limitations, a second case was investigated using remote sensing data over the less polluted Southern Ocean region. The results indicate that cloud drop size is reduced more for a fixed increase in aerosol particles during periods of higher ocean chlorophyll A. Potential biases in the results owing to statistical issues in the data analysis are discussed.
\end{abstract}

\section{Introduction}

Since oceans cover $\sim 70 \%$ of the earth surface, they represent a massive source of gaseous and aerosol emissions that mix with ship and continental emissions to form a highly complex soup of marine aerosol particles. Aerosols directly interact with solar radiation via scattering and absorption of light, and they also serve as cloud condensation nuclei (CCN) and influence cloud properties and reflectivity. Attention to the importance of aerosols in cloud and rain formation can be traced back several decades ago to observations that maritime clouds exhibit lower droplet concentrations than similar clouds influenced by anthropogenic emissions over continental areas, and that the maritime clouds often rain in less than 30 minutes [1-3]. Since that time, research has pointed to two critical pieces of information linking aerosols to warm clouds: (i) more numerous subcloud aerosol particles result in more reflective clouds (all else being fixed) because of more abundant and smaller cloud droplets [4] and (ii) for more numerous and smaller cloud droplets, suppressed droplet collision-coalescence results in less precipitation [5]. But observational and modeling studies often provide conflicting results with regard to the magnitude and even the sign of aerosol effects on clouds and precipitation [6]. Furthermore, aerosol-cloud interactions represent the largest uncertainty in assessments of the total anthropogenic radiative forcing [7].

As shown in Figure 1 (see red arrows), aerosols are at the heart of the effect of ocean emissions on cloud properties. The sources and nature of marine aerosols are influenced by some combination of ocean emissions, ship exhaust, and transported continental emissions. The task of characterizing the optically and CCN-relevant properties of marine aerosols is overwhelming owing to the difficulty in their measurement, their short atmospheric lifetime in the marine atmosphere, their spatial inhomogenieties, and the complexity of their composition. Just the organic fraction of aerosols alone is thought to comprise over thousands of species that are virtually impossible to speciate altogether [8]. While it has long been known that ocean-emitted dimethylsulfide (DMS) plays a major role in influencing the marine CCN budget [9-11], recent studies have pointed to the importance of other trace gas emissions such as isoprene $[12-15]$ and organic amines $[16,17]$, which can partition 


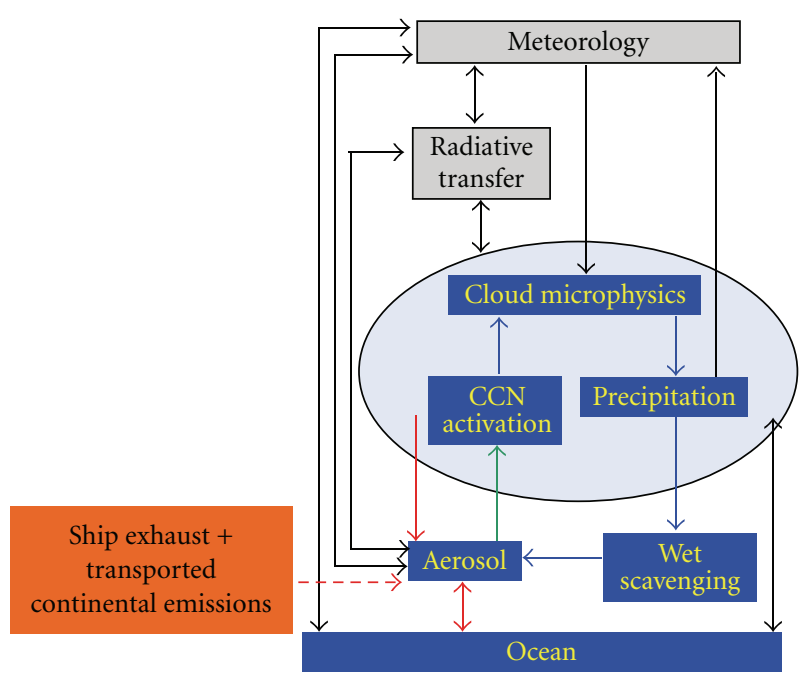

FIGURE 1: Illustration of the interactive processes between oceans, aerosols, clouds, meteorology, and radiation in the marine atmosphere. The red arrows represent the sources of aerosols and the green and blue arrows collectively encompass the microphysical processes associated with aerosol-cloud-precipitation interactions.

into the aerosol phase via secondary formation mechanisms [18-31]. Also, the importance of primary emissions of sea spray aerosols has long been recognized, but the significance of primary biological aerosol particles is becoming more evident as they have been shown to influence marine atmospheric processes more than previously assumed [3241]. Although more will be learned about the physicochemical properties of marine aerosols with advances in instrumentation, a remaining uncertainty is the extent to which various aerosol physicochemical properties affect the cloud microphysical and radiative response of clouds.

The effect of aerosols on clouds begins with the process of cloud drop activation (Figure 1, green arrow). Observational and modeling studies suggest that aside from dynamic effects (e.g., cloud base updraft velocity), the most important aerosol physicochemical parameter governing cloud drop number concentration $\left(N_{d}\right)$ is the aerosol size distribution [42-46], while aerosol composition is argued to be of secondary importance [45]. However, under certain conditions related to the degree of aerosol abundance or updraft velocity strength, chemical effects have been shown to rival the aerosol size distribution with regard to the value of $N_{d}$ [47]. The current understanding of the drop activation process has benefited from both aerosol-CCN (e.g., [4852]) and aerosol/CCN- $N_{d}$ closure studies (e.g., $[44,53-55]$ ). Although past closure studies have been met with limited success, one study in particular, that carried out an aerosol$N_{d}$ closure analysis using a cloud parcel model and aircraft measurements from a single platform [44], showed that $N_{d}$ within adiabatic cloud regions was within 15\% (on average) of predictions. The accuracy of the drop activation process in models will continue to benefit from future studies of this nature using improved experimental techniques.
In addition to drop activation, the overall microphysical response of clouds (e.g., drop size) to aerosols is highly uncertain owing to the difficulty in untangling aerosol effects on clouds in a buffered system [56]. Observational studies face the challenging task of relating aerosol perturbations to cloud microphysical responses (Figure 1, green and blue arrows) while removing meteorological effects. A failure to account for such meteorological factors, which refer to largescale thermodynamic and dynamic parameters that dictate cloud properties on a larger scale, will yield misleading results. The introduction of state-of-the-art observational tools such as NASA's A-Train constellation of satellites [57] has provided valuable information related to aerosol and cloud properties with a high degree of spatial and temporal coverage that cannot be obtained with dedicated field studies. Therefore, although there are many holes in the current knowledge related to marine aerosols and their effect on clouds and climate, new observational platforms are providing an unprecedented view of ocean-aerosol-cloud interactions.

The goal of this work is twofold: (i) present two case studies that examine ocean effects on aerosol-cloud interactions, specifically examining the steps leading from ocean emissions to a change in cloud drop size and (ii) discuss how results from these case studies can improve future attempts to quantify the links between oceans, aerosol particles, and clouds. Experimental methods used in this work are first briefly summarized. Then results are highlighted from a recent case study in the eastern Pacific Ocean region, where the drawbacks of that work are used to motivate a second case study in the Southern Ocean region that is subsequently described in detail.

\section{Experimental Methods}

Two case studies are presented below to explore ocean effects on aerosol-cloud interactions. In both case studies, ocean chlorophyll A data are used from the Sea-viewing Wide Field-of-view Sensor (Sea-WiFS; 8-day averaged data). Chlorophyll A is a proxy measurement of phytoplankton biomass and caution must be exercised when interpreting it as a proxy for primary production (i.e., biota emissions). The first case study focusing on the eastern Pacific Ocean region $\left(35.5^{\circ} \mathrm{N}-37^{\circ} \mathrm{N}, 122^{\circ} \mathrm{W}-123.5^{\circ} \mathrm{W}\right)$ is described in detail elsewhere [17], but is revisited here to highlight findings that motivate the second case study. Briefly, aerosol, cloud, and meteorological measurements were carried out on-board the Center for Interdisciplinary Remotely-Piloted Aircraft Studies (CIRPAS) Twin Otter as part of the Marine Stratus/Stratocumulus Experiment (MASE II) in July 2007. The relevant instrumentation ([17, see Table 1]) included a forward scattering spectrometer probe (cloud drop distribution), a particle-into-liquid sampler (watersoluble composition) [58], a differential mobility analyzer (aerosol size distribution), and a continuous flow thermal gradient cloud condensation nuclei counter [59].

The second case study examines the spatial domain in the Southern Ocean region encompassed by the following 
TABLE 1: Summary of correlative relationships $\left(r^{2}\right)$ between ocean chlorophyll A, marine aerosols, and stratocumulus clouds during the three-week MASE II field campaign in July 2007, during which chlorophyll A levels ranged between $1.01-3.58 \mathrm{mg} \mathrm{m}^{-3}$. Owing to the short duration of the study and limited measurements of chlorophyll $\mathrm{A}(n=3)$, all data have been averaged to correspond to the time durations corresponding to each chlorophyll A measurement. Details related to the mean, standard deviation, and range of values of these parameters are discussed in detail by Sorooshian et al. [17]. (Chl A = chlorophyll A; DEA = diethylamine; $\mathrm{MSA}=$ methanesulfonate; $N_{d}=$ cloud drop number concentration; TKE $=$ turbulent kinetic energy).

\begin{tabular}{|c|c|c|c|c|c|c|c|}
\hline & Chl A & DEA & MSA & Particle Conc. & CCN $(0.3 \%)$ & $N_{d}$ & TKE \\
\hline DEA & 0.99 & & & & & & \\
\hline MSA & 1.00 & 0.98 & & & & & \\
\hline Particle Conc. & 0.10 & 0.05 & 0.07 & & & & \\
\hline CCN $(0.3 \%)$ & 0.59 & 0.69 & 0.65 & 0.13 & & & \\
\hline$N_{d}$ & 0.97 & 0.92 & 0.95 & 0.23 & 0.42 & & \\
\hline TKE & 0.97 & 1.00 & 0.99 & 0.02 & 0.75 & 0.89 & \\
\hline Wind speed & 0.78 & 0.86 & 0.94 & 0.03 & 0.96 & 0.62 & 0.95 \\
\hline
\end{tabular}

coordinates: $42^{\circ} \mathrm{S}-60^{\circ} \mathrm{S}, 180^{\circ} \mathrm{W}-180^{\circ}$ E. Cloud and aerosol parameters are obtained from the Moderate Resolution Imaging Spectroradiometer (MODIS), specifically the $1^{\circ}$ gridded aerosol index (Level 3, MODIS Collection 5) [60] and the drop effective radius (Level 2, 1-km resolution) [61]. Aerosol index (AI) is taken as the product of the $0.55 \mu \mathrm{m}$ aerosol optical depth $\times 0.55 / 0.867 \mu \mathrm{m}$ Ångstrom exponent, where the latter parameter accounts for the aerosol size distribution. MODIS is also used to derive cloud liquid water path (LWP; a product of the drop effective radius and cloud optical depth). Lower tropospheric static stability (LTSS = potential temperature difference between $700 \mathrm{hPa}$ and $1000 \mathrm{hPa}$ ) estimates are derived from the European Centre for Medium Range Weather Forecasts (ECMWF) analyses. This parameter serves as a proxy for the thermodynamic state of the atmosphere [62]. A detailed screening procedure using data from the CloudSat cloud profiling radar, ECMWFAUXiliary analysis (ECMWF-AUX), and MODIS is used to isolate only warm clouds for this case study analysis [63].

\section{Case Study in the Eastern Pacific Ocean Region}

A recent study off the coast of California pointed to the advantage of simultaneously using multiple platforms of analysis to study ocean-aerosol-cloud interactions, while also highlighting experimental limitations to studying these interactive processes in the coupled ocean-atmosphere system [17]. Table 1 presents a reanalysis of data from that study, specifically summarizing the degree of correlation between Sea-WiFS-derived chlorophyll A, meteorological parameters, and aerosol and cloud properties. Biogenic tracers were detected in the boundary layer aerosols during periods of enhanced ocean emissions, including methanesulfonate (MSA, a dimethylsulfide oxidation product) and diethylamine (DEA). These two species were highly correlated with both chlorophyll A and low-level wind speed $\left(r^{2}>0.86\right)$. Amines were shown to be a source of secondary organic aerosol in the marine atmosphere, which together with MSA accounted for as high as $14 \%$ of the mass of sulfate during the peak chlorophyll A period. It is argued that rather than predominantly being produced via new particle formation or being primarily emitted, that amines partitioned to the aerosol phase by condensation onto preexisting aerosols; this is supported by the lack of a correlation between particle concentration and either DEA/MSA/chlorophyll A $\left(r^{2} \leq\right.$ 0.1 , and with independent field $[16,64]$ and laboratory measurements [65] related to particulate amine production.

Subsaturated aerosol hygroscopic growth measurements indicated that the organic component during periods of high chlorophyll A and wind speed exhibited considerable water uptake ability. However, a critical limitation of the study was the inability to distinguish between the effect of oceanderived organics and other organics (e.g., ship emissions) on overall hygroscopicity. Enhanced CCN activity was also observed, which was attributed to both size distribution and chemical effects, but again it was not possible to confidently attribute the change in CCN activity to the ocean-derived organics owing to the region of analysis.

Although in Table 1 it is shown that MSA/DEA/ chlorophyll A are highly correlated with $N_{d}\left(r^{2} \geq 0.92\right)$, other meteorological proxies such as turbulent kinetic energy $\left(r^{2}=\right.$ 0.89 ) are also highly correlated with $N_{d}$. In order to quantify the cloud microphysical response to an aerosol perturbation, it is necessary to account for meteorological conditions. In other words, clouds with similar LWP (or some closelyrelated proxy) should be compared when determining how cloud droplet size varies with the subcloud aerosol concentration. Short-term field studies are faced with the challenge of obtaining a significant range of aerosol variability in bins of cloud LWP to afford a robust calculation of an aerosol effect on cloud properties. For example, after removing data clearly influenced by anthropogenic pollution (using particle concentration data and back-trajectory analysis) in the current case study, only three events can be identified exhibiting a narrow range of meteorological conditions (turbulent kinetic energy was used as the meteorological proxy) to compare subcloud CCN to $N_{d}\left(r^{2}=0.41\right)$. Similarly, only three events were isolated with a narrow range of subcloud CCN concentration to correlate the turbulent kinetic energy to $N_{d}\left(r^{2}=0.95\right)$. Therefore, the limited dataset indicates that meteorology influenced $N_{d}$ to a greater extent than aerosol effects, and that aerosol perturbations as 
a result of higher chlorophyll A and wind speed may have had a secondary effect on $N_{d}$.

Two key limitations in this case study included the region of analysis and the difficulty in obtaining a sufficiently wide range of aerosol conditions with surface- and aircraft-based measurements to robustly quantify links between aerosol perturbations and cloud microphysical responses at fixed meteorological conditions (i.e., LWP). The region off the coast of California is characterized by a significant amount of background anthropogenic pollution, which makes it difficult to identify a causal relationship between ocean emissions and cloud properties (i.e., change in drop size). Generally speaking, targeting links between ocean emissions and aerosol and cloud properties may be difficult in many regions of the globe where field studies are carried out owing to the significant amount of background pollution in the form of aged ship emissions and transported continental emissions. A region that likely qualifies as a better ambient laboratory to study the effects of marine biota emissions on cloud properties is the Southern Ocean, which is the focus of the next case study that leverages satellite data. Limitations in data from dedicated field campaigns, as noted above, strongly motivate the use of satellite data, which afford greater temporal and spatial coverage (i.e., greater chance of achieving a wide range of aerosol conditions as a function of cloud regime).

\section{Case Study in the Southern Ocean Region}

This case study is motivated by previous work based on satellite-based observations in the Southern Ocean region, which indicated that a link exists between phytoplankton and cloudiness [13]. More specifically, cloud drop effective radius was shown to be reduced during periods of enhanced chlorophyll A, suggesting that enhanced phytoplankton emissions lead to higher $N_{d}$. However, there is uncertainty as to whether the inverse correlation between chlorophyll A and drop effective radius is a robust relationship in different global regions $[17,66]$.

The cloud microphysical response to aerosol perturbations is quantified in this analysis using the following Aerosol-Cloud Interaction metric [67]:

$$
\mathrm{ACI}_{r}=-\frac{\partial \ln r_{e}}{\partial \ln \alpha} \quad(\text { range }=0-0.33)
$$

where $r_{e}$ is the drop effective radius (at cloud top using MODIS), $\alpha$ is a subcloud CCN proxy (AI in this analysis), and the partial derivative is evaluated with meteorological conditions held fixed (i.e., LWP). A higher value of $\mathrm{ACI}_{r}$ can be interpreted as meaning that for a fixed increase in AI, drop radius decreases more (all else fixed). The analysis is conducted for 11 LWP bins between 50 and $350 \mathrm{~g} \mathrm{~m}^{-2}$ and for varying degrees of atmospheric stability, where data are separated into conditions of relatively low stability (LTSS < $15^{\circ} \mathrm{C}$ ) and high stability (LTSS $>18^{\circ} \mathrm{C}$ ). While the data are stratified into meteorological bins, it is noted that there still is room for meteorological variability owing to measurement uncertainties and because the bins still exhibit a finite range of values. Satellite-derived $\mathrm{ACI}_{r}$ values are reported only

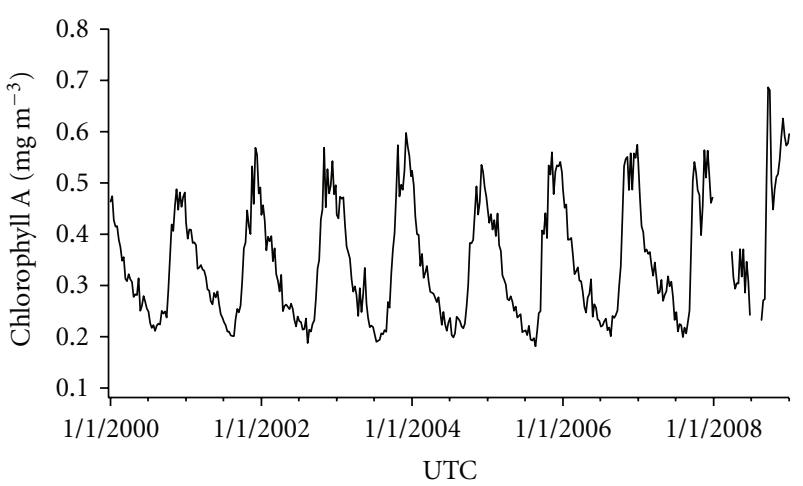

Figure 2: Time series of 8-day averaged Sea-WiFS chlorophyll A concentration in Southern Ocean region $\left(42^{\circ} \mathrm{S}-60^{\circ} \mathrm{S}, 180^{\circ} \mathrm{W}-\right.$ $\left.180^{\circ} \mathrm{E}\right)$.

when they statistically significant with $95 \%$ confidence (1tailed $\mathrm{T}$ distribution).

Figure 2 displays the time series of chlorophyll A, where it is clearly evident that there are periods of enhanced phytoplankton biomass, usually between October and February. Previous field-based studies have also identified clear seasonal differences in CCN and $N_{d}$, with increases during summer months (e.g., January and February) [68, 69], but the enhancement is less pronounced for $N_{d}$ [69]. Although higher values of ocean chlorophyll A exist in smaller spatial domains in the Southern Ocean, this analysis is carried out for a large area to ensure there is a sufficient amount of data to provide a robust calculation of $\mathrm{ACI}_{r}$ in the numerous macrophysical bins employed. In order to compare $\mathrm{ACI}_{r}$ during periods of relatively low and high chlorophyll A, data is split into three time periods ranging between OctoberFebruary $\left(>0.3 \mathrm{mg} \mathrm{m}^{-3}\right)$, March-September $\left(<0.3 \mathrm{mg} \mathrm{m}^{-3}\right)$, and April-August $\left(<0.3 \mathrm{mg} \mathrm{m}^{-3}\right)$. The latter two time periods represent low chlorophyll A conditions, but differ in time range to demonstrate the biasing effect of varying sample sizes on the absolute magnitude of $\mathrm{ACI}_{r}$. Although the data from April and August were removed for the results reported here, the conclusions of the sample size comparison are robust regardless of which months of data are removed.

Figure 3 summarizes the results of the $\mathrm{ACI}_{r}$ analysis. For low LTSS conditions $\left(<15^{\circ} \mathrm{C}\right), \mathrm{ACI}_{r}$ ranges in value between $0.06-0.19$ over the LWP range studied, while for more stable conditions (LTSS $>18^{\circ} \mathrm{C}$ ) the values range between 0.04-0.05. All of the $\mathrm{ACI}_{r}$ values are contained within the expected range of values for $\mathrm{ACI}_{r}[0-0.33 ; 67,70]$ and are consistent with values obtained in other satellitebased studies [62, 70-72]. A peculiar feature of these data is that much fewer data points are statistically significant for more stable conditions; furthermore, those statistically significant values at high LTSS exhibit the smallest overall $\mathrm{ACI}_{r}$ values. This is hypothesized to be due to the difficulty in observing the $\mathrm{ACI}_{r}$ signal in clouds with greater dynamical suppression. The striking result of this analysis is that the majority of data points exhibit higher $\mathrm{ACI}_{r}$ during periods of higher chlorophyll A. The difference in $\mathrm{ACI}_{r}$ is even greater when using the wider time range to represent low chlorophyll 
TABLE 2: Statistical summary of the $\mathrm{ACI}_{r}$ analysis shown in Figure 3. The numbers reported below represent ratios of a particular parameter between periods of relatively high chlorophyll A ( $>0.3 \mathrm{mg} \mathrm{m}^{-3}$; October-February) versus low chlorophyll A ( $<0.3 \mathrm{mg} \mathrm{m}^{-3}$; April-August). The average and standard deviation calculations are based on 11 values representing individual LWP bins between 50 and $350 \mathrm{~g} \mathrm{~m}^{-2}$. These results represent 27 months of data starting in June 2006 for the Southern Ocean region $\left(42^{\circ} \mathrm{S}-60^{\circ} \mathrm{S}, 180^{\circ} \mathrm{W}-180^{\circ} \mathrm{E}\right)$. $(\mathrm{AI}=\mathrm{aerosol}$ index; $\mathrm{AOD}=$ aerosol optical depth; $\mathrm{ANG}=$ Ångstrom exponent; $r_{e}=$ cloud drop effective radius; $\min =$ minimum value; $\max =$ maximum value) .

\begin{tabular}{|c|c|c|c|c|c|c|c|c|c|c|c|c|}
\hline & $\begin{array}{c}\mathrm{AI} \\
(\mathrm{min})\end{array}$ & $\begin{array}{c}\mathrm{AI} \\
(\max )\end{array}$ & $\begin{array}{c}\text { AI } \\
\text { (range) }\end{array}$ & $\begin{array}{l}\text { AOD } \\
(\mathrm{min})\end{array}$ & $\begin{array}{l}\text { AOD } \\
(\max )\end{array}$ & $\begin{array}{c}\text { AOD } \\
\text { (range) }\end{array}$ & $\begin{array}{l}\text { ANG } \\
(\mathrm{min})\end{array}$ & $\begin{array}{l}\text { ANG } \\
(\max )\end{array}$ & $\begin{array}{c}\text { ANG } \\
\text { (range) }\end{array}$ & $\begin{array}{c}r_{e} \\
(\mathrm{~min})\end{array}$ & $\begin{array}{c}r_{e} \\
(\max )\end{array}$ & $\begin{array}{c}r_{e} \\
\text { (range) }\end{array}$ \\
\hline Average & 3.46 & 1.69 & 1.55 & 1.51 & 1.20 & 1.19 & 2.57 & 1.39 & 1.33 & 1.15 & 0.99 & 0.94 \\
\hline $\begin{array}{l}\text { Std. } \\
\text { Dev. }\end{array}$ & 0.77 & 0.38 & 0.39 & 0.47 & 0.37 & 0.39 & 1.18 & 0.34 & 0.34 & 0.38 & 0.03 & 0.14 \\
\hline
\end{tabular}

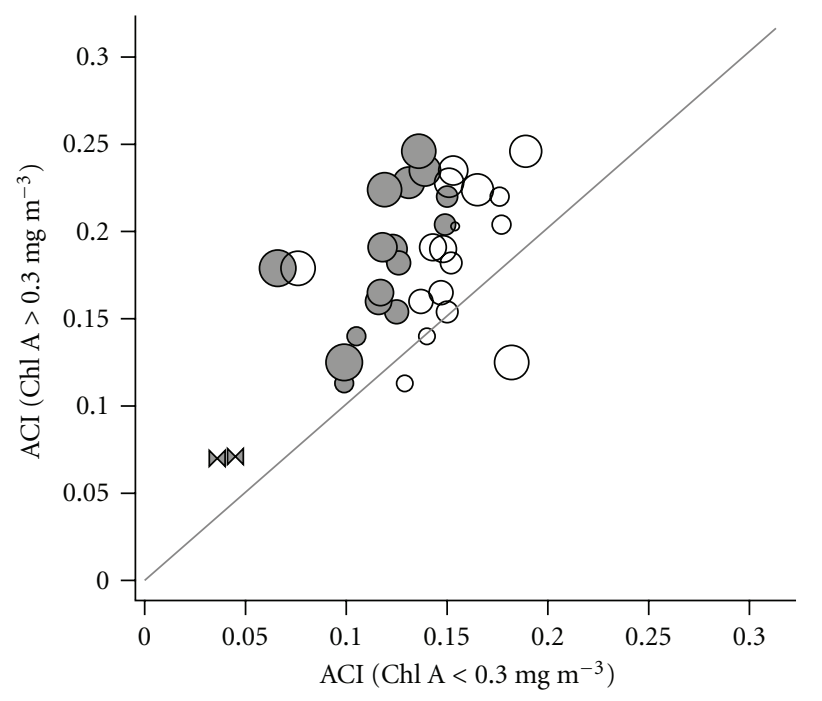

LTSS $<15 \mathrm{C}, 1.5-2$ times as many points for low Chl A LTSS $<15 \mathrm{C}$, same sample size for high and low Chl A $\bowtie$ LTSS > $18 \mathrm{C}$, same sample size for high and low Chl A

FIgURe 3: Comparison of $\mathrm{ACI}_{r}$ values (1) for periods of relatively high and low chlorophyll A concentration in the Southern Ocean region based on data over a span of 27 months starting in June 2006. Marker sizes are proportional to LWP between 50 and $350 \mathrm{~g} \mathrm{~m}^{-2}(11$ total LWP bins).

A conditions; this is presumably a result of larger sample sizes (greater by a factor of $\sim 1.5-2$ ), and consequently a dampening of the $\mathrm{ACI}_{r}$ signal owing to a greater likelihood of mixing different macrophysical conditions. To emphasize that using a larger sample size at similar chlorophyll A conditions will reduce the $\mathrm{ACI}_{r}$ signal, $\mathrm{ACI}_{r}$ is larger during the April-August time frame by a factor of $1.35 \pm 0.28$ as compared to the March-September period.

When comparing comparable sample sizes for conditions of high chlorophyll A and low chlorophyll A (April-August), the value of $\mathrm{ACI}_{r}$ during the former period is greater by a factor of $1.3 \pm 0.3$. This result suggests that during periods of higher phytoplankton biomass a fixed increase in aerosol particles more strongly suppresses $r_{e}$ because of more droplets for a fixed amount of cloud water. If this is the case, a potential explanation for these results is that those marine aerosols during periods of higher chlorophyll A may exhibit more favorable physicochemical properties (i.e., size distribution and chemical properties) with regard to droplet activation. However, cautionary notes apply with regard to this conclusion owing to measurement and statistical uncertainties. Table 2 highlights the issue of whether a "fair" statistical comparison was conducted during the identified periods of high and low chlorophyll A conditions; it is hypothesized that a wider dynamic range in AI during periods of high chlorophyll A results in a more pronounced ACI signal using satellite data. Several ratios (minimum, maximum, range) are reported between periods of high versus low chlorophyll A for AI, AOD, Ångstrom exponent, and $r_{e}$. It is shown that during periods of higher chlorophyll $\mathrm{A}$, the minimum, maximum, and overall range of AI values was larger than those for low chlorophyll A conditions. Of the two AI subcomponents (AOD and Angstrom exponent), the range in the Angstrom exponent was larger $(\sim 1.33)$ as compared to AOD (1.19) during high chlorophyll A periods versus low chlorophyll A periods. (It is noted that using $\mathrm{AOD}$ as the subcloud CCN proxy in (1) results in an $\mathrm{ACI}_{r}$ enhancement of $1.23 \pm 0.66$, which is slightly less than that when using AI.) No enhancement was evident for cloud drop effective radius (when analyzed in bins of cloud LWP), which was relatively similar for the two chlorophyll A conditions. Owing to the wider range of AI (and higher overall absolute values) during the period of enhanced chlorophyll $\mathrm{A}$, it is suspected that the $\mathrm{ACI}_{r}$ signal is more pronounced. The likely reason that the $r_{e}$ values were more similar as compared to AI (and its subcomponents) is that marine aerosols are more closely linked physically to ocean emissions than clouds (Figure 1). Therefore, although a link between higher chlorophyll A and enhanced AI values seems to be evident, the effect on cloud properties cannot be identified with high confidence using this dataset owing at least partly to statistical factors in this analysis.

\section{Conclusions}

Two case studies were discussed that explore ocean effects on aerosol-cloud interactions in regions with different levels of background anthropogenic pollution: off the California coast and the Southern Ocean. The first study that is reviewed briefly in this work off the California coast [17] leveraged simultaneous satellite and field measurements to show a direct link between ocean emissions and aerosol 
physicochemical properties during periods of enhanced chlorophyll A and low-level wind speed, which otherwise would not have been identified with any one measurement platform alone. That work also pointed to the advantage of each individual platform of analysis (ground, airborne, satellite); for example, the aircraft measurements provided unique insight into the detailed aerosol physicochemical properties and their vertical atmospheric profiles. But a drawback with the aircraft and ground-based measurements was the difficulty in obtaining a wide range of aerosol conditions at fixed meteorological conditions to robustly quantify the cloud microphysical response to aerosol perturbations during periods of varying ocean productivity. Furthermore, that region is characterized by a significant amount of background anthropogenic pollution, which made it challenging to isolate the effect of ocean biota emissions on cloud properties.

Owing to the ambiguity of the results related to ocean emissions on aerosol-cloud interactions in the first case study, a second investigation was carried out for the Southern Ocean region owing to its lower amount of background anthropogenic pollution. In order to examine aerosol effects on clouds in this area during periods of relatively low and high chlorophyll A conditions, $\mathrm{ACI}_{r}(1)$ was quantified while accounting for macrophysical factors such as atmospheric stability and cloud LWP. The cloud microphysical response to aerosol perturbations was stronger (higher $\mathrm{ACI}_{r}$ ) during periods of higher chlorophyll A. This indicates that cloud drop size experiences a greater reduction for a fixed increase in aerosol concentration, potentially as a result of aerosols with more favorable physicochemical properties for droplet activation. But a causal relationship is difficult to establish owing to biasing factors in the datasets. It is shown that during periods of higher chlorophyll $\mathrm{A}$, the range and minimum/maximum values of $\mathrm{AI}$ and its subcomponents (AOD and Angstrom exponent) are higher than those during low-chlorophyll A periods. Although this points to higher aerosol concentrations during times characterized by enhanced phytoplankton biomass, it also suggests that the $\mathrm{ACI}_{r}$ signal may be more pronounced owing to the wider range in AI. It is argued that this does not allow for a "fair" comparison and it points to the need to consider such issues in future studies. Another factor shown to bias $\mathrm{ACI}_{r}$ values is sample size, where an increase in the amount of data led to a reduction in $\mathrm{ACI}_{r}$ for conditions of low chlorophyll A presumably owing to a greater likelihood of mixing data across a wider range of meteorological and cloud conditions.

The topic of ocean-aerosol-cloud interactions will benefit from future analyses with more extensive datasets at higher spatial resolution. Field measurements are needed in addition to satellite observations to quantify the physicochemical properties of marine aerosols (e.g., size and composition) and to probe more detailed issues such as the role of surface-active and directly-emitted aerosol particles [73-78] in influencing $N_{d}$ and cloud albedo. In addition, complementary modeling-based studies (e.g., [79-84]), are essential in advancing predictions of marine aerosol emissions and their impacts on clouds and climate.

\section{Acknowledgments}

We acknowledge support from Office of Naval Research grant N00014-10-1-0811. The authors acknowledge Matt Lebsock for assistance with satellite data. Ocean chlorophyll A data used in this study were acquired using the GES-DISC Interactive Online Visualization ANd aNalysis Infrastructure (Giovanni) as part of the NASA's Goddard Earth Sciences (GES) Data and Information Services Center (DISC).

\section{References}

[1] P. Squires, "The microstructure of cumuli in maritime and continental air," Tellus, vol. 8, pp. 443-444, 1956.

[2] P. Squires, "Penetrative downdraughts in cumuli," Tellus, vol. 10, pp. 381-389, 1958.

[3] P. Squires and S. Twomey, "A comparison of cloud nucleus measurements over central north america and caribbean sea," Journal of the Atmospheric Sciences, vol. 23, pp. 401-404, 1966.

[4] S. Twomey, "Influence of pollution on shortwave albedo of clouds," Journal of the Atmospheric Sciences, vol. 34, pp. 11491152, 1977.

[5] B. A. Albrecht, "Aerosols, cloud microphysics, and fractional cloudiness," Science, vol. 245, no. 4923, pp. 1227-1230, 1989.

[6] A. P. Khain, "Notes on state-of-the-art investigations of aerosol effects on precipitation: a critical review," Environmental Research Letters, vol. 4, no. 1, Article ID 015004, 2009.

[7] IPCC, "Summary for policymakers," in Climate Change 2007: The Physical Science Basis. Contribution of Working Group I to the Fourth Assessment Report of the Intergovernmental Panel on Climate Change, S. Solomon, D. Qin, M. Manning, et al., Eds., Cambridge University Press, New York, NY, USA, 2007.

[8] A. H. Goldstein and I. E. Galbally, "Known and unexplored organic constituents in the earth's atmosphere," Environmental Science and Technology, vol. 41, no. 5, pp. 1514-1521, 2007.

[9] M. O. Andreae and H. Raemdonck, "Dimethyl sulfide in the surface ocean and the marine atmosphere: a global view," Science, vol. 221, no. 4612, pp. 744-747, 1983.

[10] G. E. Shaw, "Bio-controlled thermostasis involving the sulfur cycle," Climatic Change, vol. 5, no. 3, pp. 297-303, 1983.

[11] R. J. Charlson, J. E. Lovelock, M. O. Andreae, and S. G. Warren, "Oceanic phytoplankton, atmospheric sulphur, cloud albedo and climate," Nature, vol. 326, no. 6114, pp. 655-661, 1987.

[12] M. Claeys, B. Graham, G. Vas et al., "Formation of secondary organic aerosols through photooxidation of isoprene," Science, vol. 303, no. 5661, pp. 1173-1176, 2004.

[13] N. Meskhidze and A. Nenes, "Phytoplankton and cloudiness in the southern ocean," Science, vol. 314, no. 5804, pp. 14191423, 2006.

[14] S. R. Arnold, D. V. Spracklen, J. Williams et al., "Evaluation of the global oceanic isoprene source and its impacts on marine organic carbon aerosol," Atmospheric Chemistry and Physics, vol. 9, no. 4, pp. 1253-1262, 2009.

[15] S. Ekström, B. Nozière, and H.-C. Hansson, "The cloud condensation nuclei $(\mathrm{CCN})$ properties of 2-methyltetrols and $\mathrm{C}_{3}-\mathrm{C}_{6}$ polyols from osmolality and surface tension measurements," Atmospheric Chemistry and Physics, vol. 9, no. 3, pp. 973-980, 2009.

[16] M. C. Facchini, S. Decesari, M. Rinaldi et al., "Important source of marine secondary organic aerosol from biogenic amines," Environmental Science and Technology, vol. 42, no. 24, pp. 9116-9121, 2008. 
[17] A. Sorooshian, L. T. Padró, A. Nenes, et al., "On the link between ocean biota emissions, aerosol, and maritime clouds: airborne, ground, and satellite measurements off the coast of California," Global Biogeochemical Cycles, vol. 23, no. 4, Article ID GB4007, p. 15, 2009.

[18] C. D. O'Dowd and G. de Leeuw, "Marine aerosol production: a review of the current knowledge," Philosophical Transactions of the Royal Society A, vol. 365, no. 1856, pp. 1753-1774, 2007.

[19] J. Liggio, S.-M. Li, and R. McLaren, "Heterogeneous reactions of glyoxal on particulate matter: identification of acetals and sulfate esters," Environmental Science and Technology, vol. 39, no. 6, pp. 1532-1541, 2005.

[20] R. Volkamer, P. J. Ziemann, and M. J. Molina, "Secondary organic aerosol formation from acetylene $(\mathrm{C} 2 \mathrm{H} 2)$ : seed effect on SOA yields due to organic photochemistry in the aerosol aqueous phase," Atmospheric Chemistry and Physics, vol. 9, no. 4, pp. 1907-19028, 2009.

[21] A. L. Corrigan, S. W. Hanley, and D. O. De Haan, "Uptake of glyoxal by organic and inorganic aerosol," Environmental Science and Technology, vol. 42, no. 12, pp. 4428-4433, 2008.

[22] C. J. Hennigan, M. H. Bergin, J. E. Dibb, and R. J. Weber, "Enhanced secondary organic aerosol formation due to water uptake by fine particles," Geophysical Research Letters, vol. 35, no. 18, Article ID L18801, 5 pages, 2008.

[23] J. D. Blando and B. J. Turpin, "Secondary organic aerosol formation in cloud and fog droplets: a literature evaluation of plausibility," Atmospheric Environment, vol. 34, no. 10, pp. 1623-1632, 2000.

[24] P. Warneck, "In-cloud chemistry opens pathway to the formation of oxalic acid in the marine atmosphere," Atmospheric Environment, vol. 37, no. 17, pp. 2423-2427, 2003.

[25] K. K. Crahan, D. Hegg, D. S. Covert, and H. Jonsson, "An exploration of aqueous oxalic acid production in the coastal marine atmosphere," Atmospheric Environment, vol. 38, no. 23, pp. 3757-3764, 2004.

[26] B. Ervens, G. Feingold, G. J. Frost, and S. M. Kreidenweis, "A modeling of study of aqueous production of dicarboxylic acids: 1. Chemical pathways and speciated organic mass production," Journal of Geophysical Research, vol. 109, no. 15, Article ID D15205, 20 pages, 2004.

[27] J. Z. Yu, X.-F. Huang, J. Xu, and M. Hu, "When aerosol sulfate goes up, so does oxalate: implication for the formation mechanisms of oxalate," Environmental Science and Technology, vol. 39, no. 1, pp. 128-133, 2005.

[28] A. Sorooshian, V. Varutbangkul, F. J. Brechtel et al., "Oxalic acid in clear and cloudy atmospheres: analysis of data from international consortium for atmospheric research on transport and transformation 2004," Journal of Geophysical Research, vol. 111, no. 23, Article ID D23S45, 17 pages, 2006.

[29] A. Sorooshian, M.-L. Lu, F. J. Brechtel et al., "On the source of organic acid aerosol layers above clouds," Environmental Science and Technology, vol. 41, no. 13, pp. 4647-4654, 2007.

[30] A. G. Carlton, B. J. Turpin, K. E. Altieri et al., "Atmospheric oxalic acid and SOA production from glyoxal: results of aqueous photooxidation experiments," Atmospheric Environment, vol. 41, no. 35, pp. 7588-7602, 2007.

[31] K. E. Altieri, S. P. Seitzinger, A. G. Carlton, B. J. Turpin, G. C. Klein, and A. G. Marshall, "Oligomers formed through incloud methylglyoxal reactions: chemical composition, properties, and mechanisms investigated by ultra-high resolution FTICR mass spectrometry," Atmospheric Environment, vol. 42, no. 7, pp. 1476-1490, 2008.

[32] M. L. Wells and E. D. Goldberg, "Occurrence of small colloids in sea water,” Nature, vol. 353, no. 6342, pp. 342-344, 1991.
[33] M. L. Wells and E. D. Goldberg, "Colloid aggregation in seawater," Marine Chemistry, vol. 41, no. 4, pp. 353-358, 1993.

[34] R. Benner, J. D. Pakulski, M. McCarthy, J. I. Hedges, and P. G. Hatcher, "Bulk chemical characteristics of dissolved organic matter in the ocean," Science, vol. 255, no. 5051, pp. 15611564, 1992.

[35] M. L. Wells, "Marine colloids-a neglected dimension," Nature, vol. 391, no. 6667, pp. 530-531, 1998.

[36] E. K. Bigg, C. Leck, and L. Tranvik, "Particulates of the surface microlayer of open water in the central Arctic Ocean in summer," Marine Chemistry, vol. 91, no. 1-4, pp. 131-141, 2004.

[37] C. Leck and E. K. Bigg, "Biogenic particles in the surface microlayer and overlaying atmosphere in the central Arctic Ocean during summer," Tellus, Series B, vol. 57, no. 4, pp. 305316, 2005.

[38] C. Leck and E. K. Bigg, "Source and evolution of the marine aerosol-a new perspective," Geophysical Research Letters, vol. 32, no. 19, Article ID L19803, 4 pages, 2005.

[39] R. Jaenicke, "Abundance of cellular material and proteins in the atmosphere," Science, vol. 308, no. 5718, 73 pages, 2005.

[40] E. K. Bigg, "Sources, nature and influence on climate of marine airborne particles," Environmental Chemistry, vol. 4, no. 3, pp. 155-161, 2007.

[41] V. R. Després, J. F. Nowoisky, M. Klose, R. Conrad, M. O. Andreae, and U. Pöschl, "Characterization of primary biogenic aerosol particles in urban, rural, and high-alpine air by DNA sequence and restriction fragment analysis of ribosomal RNA genes," Biogeosciences, vol. 4, no. 6, pp. 11271141, 2007.

[42] J. W. Fitzgerald, "Effect of aerosol composition on cloud droplet size distribution-numerical study," Journal of the Atmospheric Sciences, vol. 31, pp. 1358-1367, 1974.

[43] G. Feingold, "Modeling of the first indirect effect: analysis of measurement requirements," Geophysical Research Letters, vol. 30, no. 19, pp. 7-4, 2003.

[44] W. C. Conant, T. M. VanReken, T. A. Rissman et al., "Aerosolcloud drop concentration closure in warm cumulus," Journal of Geophysical Research, vol. 109, no. 13, Article ID D13204, 12 pages, 2004.

[45] B. Ervens, G. Feingold, and S. M. Kreidenweis, "Influence of water-soluble organic carbon on cloud drop number concentration," Journal of Geophysical Research, vol. 110, no. 18, Article ID D18211, 14 pages, 2005.

[46] U. Dusek, G. P. Frank, L. Hildebrandt et al., "Size matters more than chemistry for cloud-nucleating ability of aerosol particles," Science, vol. 312, no. 5778, pp. 1375-1378, 2006.

[47] A. Nenes, R. J. Charlson, M. C. Facchini, M. Kulmala, A. Laaksonen, and J. H. Seinfeld, "Can chemical effects on cloud droplet number rival the first indirect effect?" Geophysical Research Letters, vol. 29, no. 17, article 1848, 4 pages, 2002.

[48] T. M. VanReken, T. A. Rissman, G. C. Roberts et al., "Toward aerosol/cloud condensation nuclei (CCN) closure during CRYSTAL-FACE," Journal of Geophysical Research, vol. 108, no. D20, article 4633, 18 pages, 2003.

[49] P. S. K. Liu, W. R. Leaitch, C. M. Banic, S.-M. Li, D. Ngo, and W. J. Megaw, "Aerosol observations at chebogue point during the 1993 North Atlantic regional experiment: relationships among cloud condensation nuclei, size distribution, and chemistry," Journal of Geophysical Research, vol. 101, no. 22, pp. 28971-28990, 1996. 
[50] D. S. Covert, J. L. Gras, A. Wiedensohler, and F. Stratmann, "Comparison of directly measured CCN with CCN modeled from the number-size distribution in the marine boundary layer during ACE 1 at Cape Grim, Tasmania," Journal of Geophysical Research, vol. 103, no. 13, pp. 16597-16608, 1998.

[51] W. Cantrell, G. Shaw, G. R. Cass et al., "Closure between aerosol particles and cloud condensation nuclei at kaashidhoo climate observatory," Journal of Geophysical Research, vol. 106, no. 22, pp. 28711-28718, 2001.

[52] J. R. Snider, S. Guibert, J.-L. Brenguier, and J.-P. Putaud, "Aerosol activation in marine stratocumulus clouds: 2. Köhler and parcel theory closure studies," Journal of Geophysical Research, vol. 108, no. 15, article 8629, 23 pages, 2003.

[53] S. Twomey and J. Warner, "Comparison of measurements of cloud droplets and cloud nuclei," Journal of the Atmospheric Sciences, vol. 24, pp. 702-703, 1967.

[54] J. W. Fitzgerald and P. Spyers-Duran, "Changes in cloud nucleus concentration and cloud droplet size distribution associated with pollution from St. Louis," Journal of Applied Meteorology, vol. 30, pp. 511-516, 1973.

[55] J. R. Snider and J.-L. Brenguier, "Cloud condensation nuclei and cloud droplet measurements during ACE-2," Tellus, Series B, vol. 52, no. 2, pp. 828-842, 2000.

[56] B. Stevens and G. Feingold, "Untangling aerosol effects on clouds and precipitation in a buffered system," Nature, vol. 461, no. 7264, pp. 607-613, 2009.

[57] G. L. Stephens, D. G. Vane, R. J. Boain et al., "The cloudsat mission and the a-train: a new dimension of space-based observations of clouds and precipitation," Bulletin of the American Meteorological Society, vol. 83, no. 12, pp. 17711742, 2002.

[58] A. Sorooshian, F. J. Brechtel, Y. L. Ma, et al., "Modeling and characterization of a particle-into-liquid sampler (PILS)," Aerosol Science and Technology, vol. 40, pp. 396-409, 2006.

[59] G. C. Roberts and A. Nenes, "A continuous-flow streamwise thermal-gradient CCN chamber for atmospheric measurements," Aerosol Science and Technology, vol. 39, no. 3, pp. 206$221,2005$.

[60] L. A. Remer, Y. J. Kaufman, D. Tanré et al., "The MODIS aerosol algorithm, products, and validation," Journal of the Atmospheric Sciences, vol. 62, no. 4, pp. 947-973, 2005.

[61] S. Platnick, M. D. King, S. A. Ackerman et al., "The MODIS cloud products: algorithms and examples from terra," IEEE Transactions on Geoscience and Remote Sensing, vol. 41, no. 2, pp. 459-473, 2003.

[62] S. A. Klein and D. L. Hartmann, "The seasonal cycle of low stratiform clouds," Journal of Climate, vol. 6, no. 8, pp. 15871606, 1993.

[63] M. D. Lebsock, G. L. Stephens, and C. Kummerow, "The seasonal cycle of low stratiform clouds," Journal of Geophysical Research, vol. 113, no. 8, Article ID D15205, 12 pages, 2008.

[64] A. Sorooshian, S. M. Murphy, S. Hersey et al., "Comprehensive airborne characterization of aerosol from a major bovine source," Atmospheric Chemistry and Physics, vol. 8, no. 17, pp. 5489-5520, 2008.

[65] S. M. Murphy, A. Sorooshian, J. H. Kroll, et al., "Secondary aerosol formation from atmospheric reactions of aliphatic amines," Atmospheric Chemistry and Physics, vol. 7, no. 9, pp. 2313-2337, 2007.

[66] M. A. Miller and S. E. Yuter, "Lack of correlation between chl A and cloud droplet effective radius in shallow marine clouds," Geophysical Research Letters, vol. 35, Article ID L13807, 7 pages, 2008 .
[67] G. Feingold, L. A. Remer, J. Ramaprasad, and Y. J. Kaufman, "Analysis of smoke impact on clouds in Brazilian biomass burning regions: an extension of Twomey's approach," Journal of Geophysical Research, vol. 106, no. 19, pp. 22907-22922, 2001.

[68] G. P. Ayers and J. L. Gras, "Seasonal relationship between cloud condensation nuclei and aerosol methanesulphonate in marine air," Nature, vol. 353, no. 6347, pp. 834-835, 1991.

[69] S. S. Yum and J. G. Hudson, "Wintertime/summertime contrasts of cloud condensation nuclei and cloud microphysics over the Southern Ocean," Journal of Geophysical Research, vol. 109, no. 6, Article ID D06204, 14 pages, 2004.

[70] F.-M. Bréon, D. Tanré, and S. Generoso, "Aerosol effect on cloud droplet size monitored from satellite," Science, vol. 295, no. 5556, pp. 834-838, 2002.

[71] T. Matsui, H. Masunaga, R. A. Pielke Sr., and W.-K. Tao, "Impact of aerosols and atmospheric thermodynamics on cloud properties within the climate system," Geophysical Research Letters, vol. 31, no. 6, Article ID L06109, 4 pages, 2004.

[72] J. Quaas, O. Boucher, and F.-M. Bréon, "Aerosol indirect effects in POLDER satellite data and the laboratoire de Météorologie dynamique-zoom (LMDZ) general circulation model," Journal of Geophysical Research, vol. 109, no. 8, Article ID D08205, 9 pages, 2004.

[73] E. J. Hoffman and R. A. Duce, "Factors influencing the organic carbon content of marine aerosols: a laboratory study," Journal of Geophysical Research, vol. 81, no. 21, pp. 3667-3670, 1976.

[74] R. M. Gershey, "Characterization of seawater organicmatter carried by bubble-generated aerosols," Limnology and Oceanography, vol. 28, pp. 309-319, 1983.

[75] D. C. Blanchard, "The ejection of drops from the sea and their enrichment with bacteria and other materials: a review," Estuaries, vol. 12, no. 3, pp. 127-137, 1989.

[76] R. S. Tseng, J. T. Viechnicki, R. A. Skop, and J. W. Brown, "Sea-to-air transfer of surface-active organic compounds by bursting bubbles," Journal of Geophysical Research, vol. 97, no. 4, pp. 5201-5206, 1992.

[77] A. M. Middlebrook, D. M. Murphy, and D. S. Thomson, "Observations of organic material in individual marine particles at cape grim during the first aerosol characterization experiment (ACE 1)," Journal of Geophysical Research, vol. 103, no. 13, pp. 16475-16483, 1998.

[78] C. D. O’Dowd, M. C. Facchini, F. Cavalli et al., "Biogenically driven organic contribution to marine aerosol," Nature, vol. 431, no. 7009, pp. 676-680, 2004.

[79] G. J. Roelofs, "A GCM study of organic matter in marine aerosol and its potential contribution to cloud drop activation," Atmospheric Chemistry and Physics, vol. 8, no. 3, pp. 709-719, 2008.

[80] D. V. Spracklen, S. R. Arnold, J. Sciare, K. S. Carslaw, and C. Pio, "Globally significant oceanic source of organic carbon aerosol," Geophysical Research Letters, vol. 35, no. 12, Article ID L12811, 5 pages, 2008.

[81] B. Langmann, C. Scannell, and C. O'Dowd, "New directions: organic matter contribution to marine aerosols and cloud condensation nuclei," Atmospheric Environment, vol. 42, no. 33, pp. 7821-7822, 2008.

[82] C. D. O'Dowd, B. Langmann, S. Varghese, C. Scannell, D. Ceburnis, and M. C. Facchini, "A combined organic-inorganic sea-spray source function," Geophysical Research Letters, vol. 35, no. 1, Article ID L01801, 5 pages, 2008. 
[83] B. Gantt, N. Meskhidze, and D. Kamykowki, "A new physically-based quantification of isoprene and primary organic aerosol emissions from the world's oceans," Atmospheric Chemistry and Physics, vol. 9, pp. 4915-4927, 2009.

[84] B. Gantt, N. Meskhidze, Y. Zhang, and J. Xu, "The effect of marine isoprene emissions on secondary organic aerosol and ozone formation in the coastal United States," Atmospheric Environment, vol. 44, no. 1, pp. 115-121, 2009. 

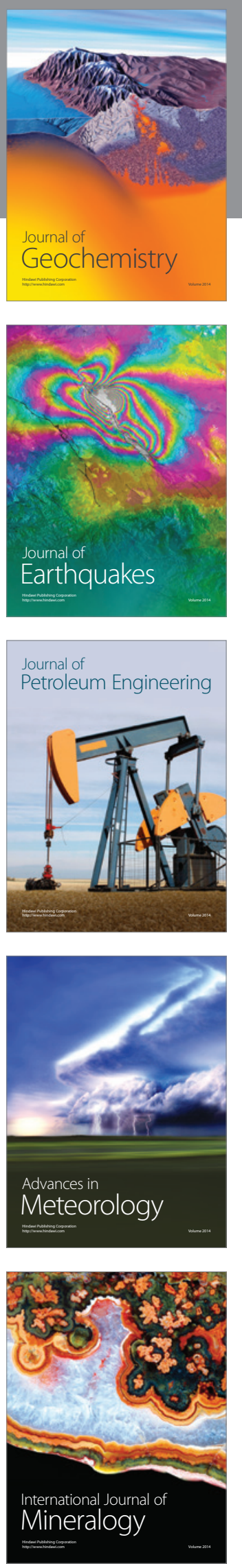
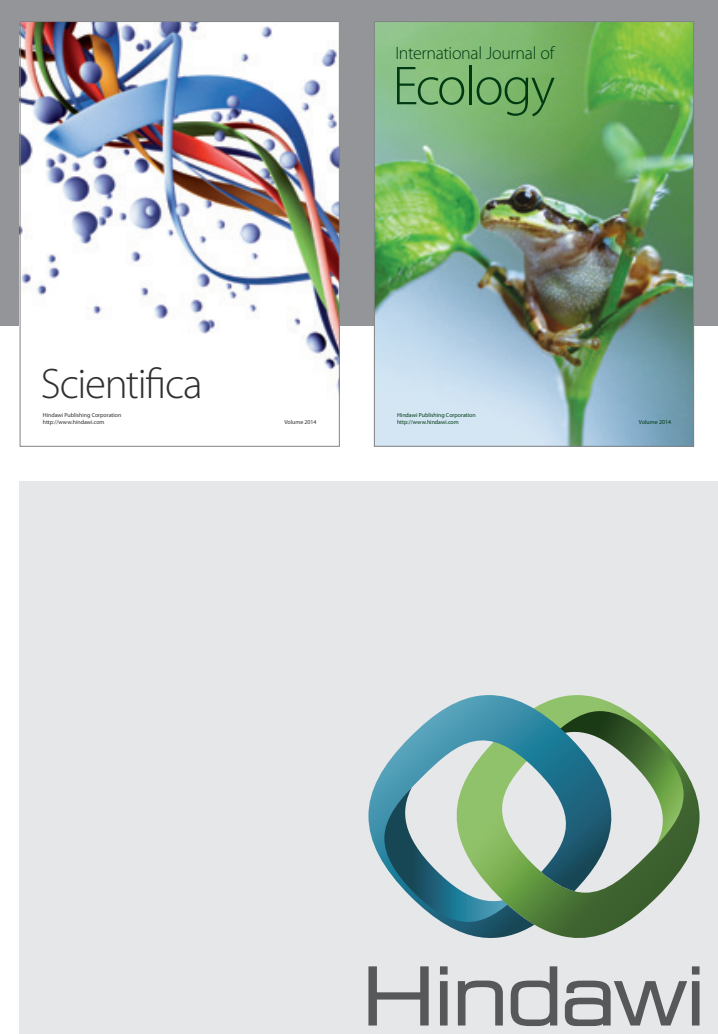

Submit your manuscripts at http://www.hindawi.com
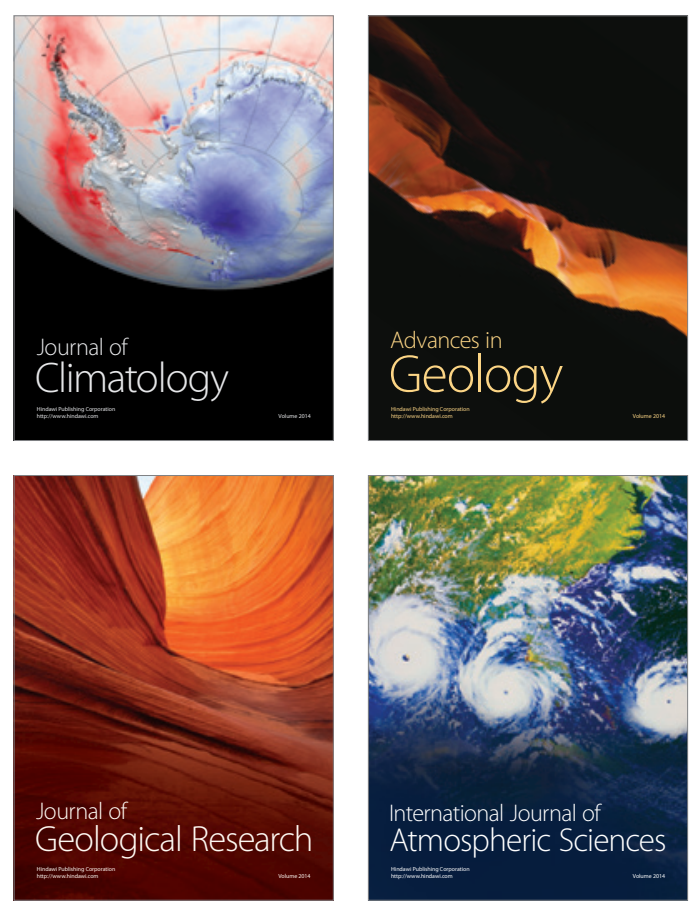
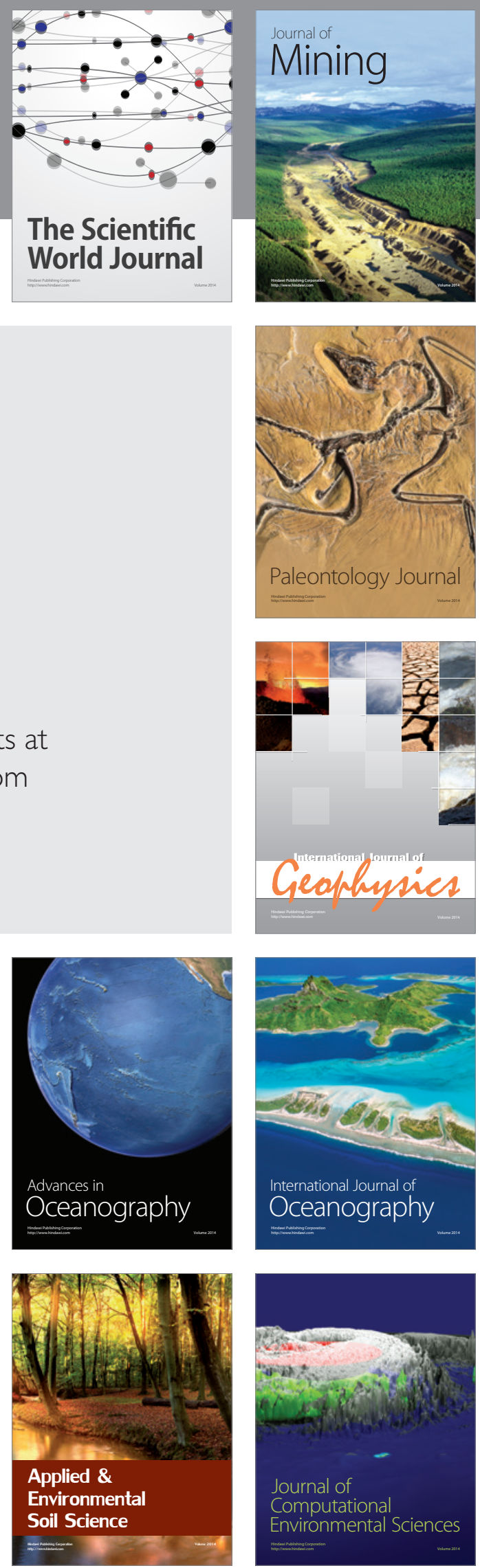